\title{
BEN-OIL IN ANCIENT EGYPT
}

\author{
Jiro KONDO*
}

\section{Introduction}

There were many kinds of oil in ancient Egypt, for example, $n h h, m r$ $h t$, sgnn, sft and so on. (1) The oil called $b 3 k$ was one of the most important oil among them. B3k was thought to be olive oil for a long time by Egyptologists. (2) However, the Egyptian word for olive was $\underline{d} t$.(3) $\underline{D} t$ from ancient Egyptian records was very rare. It first appeared in Egypt at the time of the Eighteenth Dynasty, and was probably imported from Syria. (4)

Ben-oil is produced from the seeds of Moringa peregrina Fiori (Moringa aptera Gaertn., Moringa arabica Pers.) and a very similar oil is obtained from the seeds of Moringa oleifera Lam. (Moringa pterygosperma Goertn.).(5)

The refined oil is yellowish in colour and tastes sweet. As it is odourless, it has been used as cosmetics. It was also used for cooking. In ancient Egypt, it was also used as ingredient for medicine. The Ebers papyrus shows the recipe for the remedy for stomach trouble. A mixture of honey, Moringa oil, frankincence, wine was boiled and eaten. It was also used as enema and refreshing ointment. Moringa oil was also considered to be insect repellent. (6)

Moringa tree is very tall, about 10 15 metres high, and has long pods with seeds. (7) Each pod is $20 \mathrm{~cm}$ long and consists of several seeds in it. A seed is $15 \mathrm{~mm}$. long and $12 \mathrm{~mm}$. broad on the average.(8) Today, Moringa peregrina Fiori occurs wild in the rocky region of the Upper Egypt, but very rare. It also grows naturally in Syria, South Arabia, Eritrea, Abyssinia, and Sudan.(9) Lucas identified Pliny's myrobalanum as Moringa ree. ${ }^{(10)}$

* The Egyptian Culture Center, Waseda University 


\section{B3k as Person's Names}

The words of $b 3 k$ appeared first on the wall paintings of the tomb-chapel of Pepiankh ( $\left.p p y-{ }^{\prime} n h\right)$ in Meir. This tomb is dated as belonging to the end of the Old Kingdom, the Sixth Dynasty. (11) We can find the following names as the names of people, $b 3 k,{ }^{(12)} b 3 k k,{ }^{(13)}$ and $n f r-b 3 k t(14)$ inside the tomb-chapel.

In the Eleventh Dynasty, $b 3 k t^{(15)}$ and b3kty(16) were also used for person's names in the tombs of Beni Hasan.(17)

From the end of the Old Kingdom to the beginning of the Middle Kingdom, the usage of the word $b 3 k$ was limited only to person's name. We have not any records of $b 3 k$ as referring to ben-oil until the Twelfth Dynasty in Egypt.

\section{Inscribed Records of Ben-Oil}

1. The Story of Sinuhe(18)

The story of Sinuhe is one of the most popular ancient Egyptian stories. This story has taken place in the Twelfth Dynasty. The following passage from this story is one of the earliest records referring to ben-oil in Syria. Syria seems to have been the main producing country of ben-oil in the ancient time.

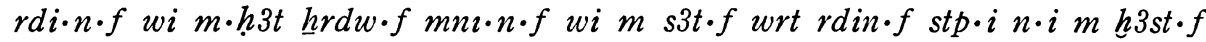

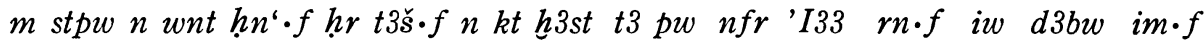
$h n$ ' i3rrt wr n.f irp $r m w$ '3 bit.f 'š b3k.f dkrw nb hr hltw.f iw it im $h n$ ' bty nn $\underline{d}$ rw mnmnt nbt '3 grt dmit $r \cdot i m$ ii $n$ mrt.i rdit.f wi $m$ hk.3 whyt $m$ stp $n$ ḩ3st.f ir $n \cdot i$ ' kw $m$ mint irp $m$ hrt hrw iwf ps 3pd $m$ 3̌s $r$ hrw-r ' wt hlsst iw grg.tw $n \cdot i$ iw w3h.tw $n \cdot i$ hrw-r inw $n$ tsmw.i iw irt

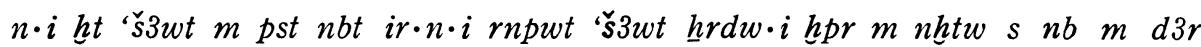
whyt.f

"He placed me in front of his children and married me to his eldest daughter. He made me take from his country the best of what he owned at the border of his land with another country. It was a good land, Yaa was its name. Figs were there as well as grapes, and wine was more plentiful than 
water. The land abounded with honey and ben-oil. All kinds of fruit were on its trees. Barley was there and also emmer, as well as a large number of cattle of different kinds. Furthermore, what I was offered by reason of his love for me was great. I was made a ruler of the best tribe in his land. Loaves were provided for me daily, and so was wine and cooked meat and roast duck as well as desert game. Men hunted for me and laid food before me in addition to the quarry of my hunting-dogs. Many good things were made for me, and boiled in every way. I spent many years while my children became fine men, each one as the head of his tribe."

\section{The Biography of Ineni}

Ineni lived through the reigns of Amenophis I, Tuthmosis I, Tuthmosis II, and Tuthmosis III at the beginning of the Eighteenth Dynasty in the New Kingdom. He served the above four kings and had the title of the "overseer of the granary of Amen". His autobiography in his tomb, the tomb No. 81 at Sheikh "Abd al-Qurna in the Theban West,(19) is an important record of the early period of the Eighteenth dynasty. In his autobiography referring to the reign of Tuthmosis II, a record of ben-oil is seen.(20) Judging from this passage ben-oil was a luxury and as it is listed with food and drinks, it seems to have been served as some sort of provision at the meal time.

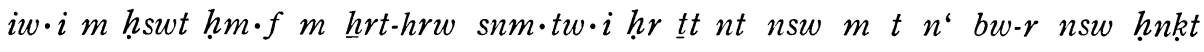
mitt iwf $\underline{d} d 3$ rnpwt dkrw šbnw bit šyt irp b3k iw nd.tw hrt.i $m$ snb 'nh $m$ $\underline{d} d h m \cdot f \underline{d} s \cdot f n m r t \cdot i$

"I received his majesty's favour every day. I was supplied from the table of the king with bread for his breakfast, beer likewise, meat, fat, vegetables, different kinds of fruits, honey, biscuit, wine, and ben-oil. I am enquired after my health and life, as his majesty himself said for my love."

3. The Fifth Campaign of Tuthmosis III

Tuthmosis III made 17 military expeditions to Asia. At his 5 th expedition in the 29th year of his reign, he went as far as the town of Tunip in the Northern Syria.(21) Ben-oil appears in the record of this expedition.(22) 
From this record, the relationship of ben-oil and the northern Syria is suggested. It also shows that ben-oil was used at special occasions such as during festivals in Egypt at that time.

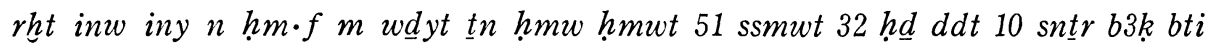
mni 470 irp mni 6428 hmt dḥty hssb $w 3 \underline{d}$ mnmnt 618 'wt 3636 t nfr $t$ šbnw

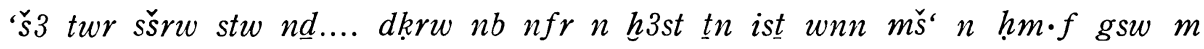
b3k $r^{\prime}$ nb mi nty ḥbw $m$ T3-mri

"The list of the gifts brought for his majesty on this campaign. 51 slaves, male female, 32 horses, 10 silver dishes, incense, ben-oil, 470 jars of honey, 6428 jars of wine, copper, lead, lapis lazuli, green stone, 618 cattle, 3636 small cattle, good loaves, many different kinds of loaves, clean grain and flour.... all good fruit of this country. Lo, the army of his majesty was drunk and anointed with ben-oil every day, as at festivals in Egypt."

4. The Private Poetical Stela (JdE. No. 28569, the Egyptian Museum, Cairo)(23)

This stela is a private poetical stela written according to a certain style and it does not seem to indicate a historical fact. Ben-oil is listed among other things brought from Asia. This stela is written after the style of other records of expeditions or tributes from Asia such as the record of the expeditions of Tuthmosis III as referred above.

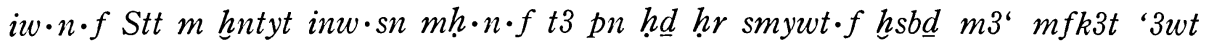

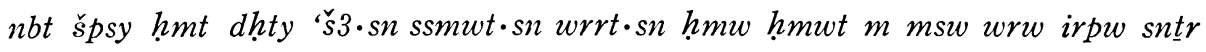
b3k $w 3 \underline{d}$ 's mrhiw tpw $n$ h̆htyw .... ssndm(?)

"There come to him the Asiatics, travelling to the south, their gifts, it filled this land, silver from its deserts, real lapis lazuli, turquoise, every kind of noble precious stone, copper and lead according to their abundance, their horses, their chariots, slaves, male and female together with the children of the chiefs, wine, incense, fresh ben-oil, cedar and resin of the best of the hillsides..... sesnedjem-wood(?)" 
Rekhmira was the vizier and the governor of the town under the kings Tuthmosis III and Amenophis II (c. 1450 BC). His tomb, Theban private No. 100, is located at Sheikh 'Abd al-Qurna. (24) This tomb has very famous wall paintings of foreign tributes from Syria and Nubia on the south side of the west wall of its hall. On the second register from the bottom, there is a tribute scene from Syria, the land of Rtnw. An Egyptian scribe is recording their tribute. In front of him, there are four smaller registers showing the gifts brought from Syria. These gifts consist of various products such as silver, gold, lead, copper, cedar, lapis lazuli, etc. And in the bottom register, there are a number of jars with inscriptions on them. The inscriptions are no longer clear but according to the record made by P. Newberry, there are three jars with the name of $b 3 k$ on them together with other jars of incense and $s f \underline{t}$ oil. Today only the determinative of tree can be identified for the inscription of $b 3 k_{.}{ }^{(25)}$ (Fig. 1-1).

On the south wall of the inner chamber of the same tomb, the name of $b 3 k$ is seen as a product of the Lower Egypt with incense and wine. This is an important evidence to indicate that ben-oil was produced in the Lower Egypt. (26)

On the north wall of the inner chamber is a scene where Rekhmira and his wife Meryt are seated to receive sistrums and menits from their daughters. There is an inscription above them. The inscription indicates that anointment with ben-oil was a pleasure. Probably, it had an effect of relaxing or soothing. The text says as follows. (27)

shmh-ib $m 33$ bw nfr ḩsi h̆bt šm" wrh 'ntyw gs $m$ b3k šsn $r$ šrt $t$ irp bniwt

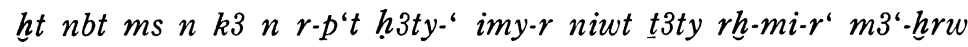

"The enjoyment of the sight of good things; music, dancing, and making music, anointment with myrrh and smearing with ben-oil, lotus to the nostril, bread, wine, date-wine, and all things, presented to the $k a$ of the hereditary noble, the governor of the town, the vizier, Rekhmire ,justified." (Fig. 1-2) 
Out of 1400 jar labels from the Palace of Malkata, excavated by the Metropolitan Museum and reported by Hayes, 22 (about 1.6\%) are reported to have the name of ben-oil on them. ${ }^{(28)}$ Other contents of the jars are wine (285), beer (298), meat (375), fat (91), fowl (18), honey (7) and beans (2). The jar labels Nos.183-196 refer to ben-oil according to Hayes. Also two jar labels of seeds of Moringa tree have been reported by Hayes (Nos. H. 215-6). Further, 177 labels have been found by the excavation of the Palace of Malkata by the University Museum of Pennsylvania during the years between 1971 and 1974. Among them 5 (2.8\%) (Nos. L. 86-90) had the name of ben-oil. Others had the names of wine (20), beer (56), meat (3), fat (2), fowl (5) and grain (3). Leahy reports the jar labels excavated by the University Museum of Pennsylvania. (29)

H. $183 \ldots . . .30$ b3k $w 3 \underline{d}$....: (Year) 30 , fresh ben-oil ....

H. 184 b3k ndm $n$ nsw Hwi $n$ p3 h̆b-sd tp $n h m \cdot f$ 'nh wd 3 snb: sweet ben-oil of the Royal Scribe Huy for the first jubilee of his Majesty 1. s. h.

H. 185 b3k $n$ t3ty Hwi $n$ p3 hb-sd ....: ben-oil of the vizier Huy for the jubilee ....

H. $186[b 3] k$ w3d $n$ p3 $h b$-sd .... p3-sr $n$ š $3 p d$ (?): fresh ben-oil for the jubilee $\ldots$. of) Paser of the Lake of the Bird.

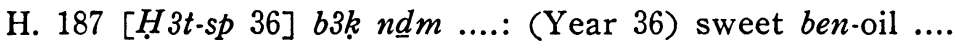

H. $183 H 3 t$-sp 37 b3k ndm $n$ hm-ntr imy-r pr Mryw-Pth: Year 37, sweet ben-oil of the prophet, the overseer of the house, Meryw-Ptah

H. $189 b 3 k \ldots . . n$ p3 $k 3 m w$ : ben-oil .... of the orchard

H. $190 b 3 k n h m-n t r$....: ben-oil of prophet

H. 191 b3k w3d $n$ whmw-nsw 'Imn-m-int; fresh ben-oil of the royal herald, Amenemonet

H. 192 [b3k] w3ㅁ $n$ sš-nsw Hwi: fresh [ben]-oil of the royal scribe, Huy

H. 193 b3k $w 3 \underline{d}$ : fresh ben-oil

H. 194 b3k tpy: ben-oil, the best

H. 195 b3k $n \underline{d} m$ : sweet ben-oil

H. 196 b3k: ben-oil 
H. 215 H3t-sp 32 prt b3k $n$ p3 k3mw m Mn-nfr $m \underline{d r t ~ i m y-r ~ ' h n w t y ~} \underline{T} 3 y$ : Year 32, seeds of Moringa tree of the orchard of Memphis in charge of the chamberlain, Tjay

H. 216 prt $b 3[k]$....: seeds of Moringa tree ....

L. 86 b3k .... ir $n$ : ben-oil .... donated by ....

L. $87 b 3 k$....: ben-oil

L. $88 b 3 k \ldots$ ir. $n \cdot f n$ : ben-oil .... he donated for ....

L. $89 \ldots$... b3k $n f r n t 3 w^{\prime} b t \ldots . .$. ... good ben-oil from the refectory

L. $90 \ldots[b 3] k w 3 \underline{d} \ldots . .$. .... fresh ben-oil

As shown above, only short inscriptions can be found. Ben-oil is characterized as "fresh" $(w 3 \underline{d})$, “sweet" $(n \underline{d} m)$, "good" $(n f r)$, "very good" (nfr $n f r)$ and "best" (tpy).

As the land that produced ben-oil, $\check{s} 3 p d$ (?) "the Lake of the Bird" on the label No. 186 is the only recorded name. The problem remains of identifying "the Lake of the Bird". Hayes, though not abandoning the possibility of $\check{s} 3 p d$ as a variant of $\check{s} k b h$ "the Lake of Waterfowl" near Heliopolis, mentions that $k b h$ "waterfowl" has so far not been known to have been written with the sign of the bird alone. ${ }^{(30)}$ Yet it is highly likely that benoil was produced in the Lower Egypt. Hayes states that the offical names inscribed on the labels are related to Memphis, Athribis and other regions of the Lower Egypt. Further, two jar labels (Hayes Nos.H.215-216) inscribed to have contained prt b3kt (the seeds or pods of the Moringa tree) have been excavated from the Palace of Malkata, and one of them mentions that these seeds had come from the orchard of Memphis as shown above (No. 215), (31) thus indicating the close relationship between the Moringa trees and Memphis, that is, probably Moringa trees were grown in the Lower Egypt.

Besides jar labels, ben-oil is also inscribed on the clay used as jar sealings. Hayes reports one and Leahy reports three examples of the jar sealings with the name of ben-oil. (Fig. 2-1, 2, 3).

H, EE. $b 3 k w 3 \underline{d} n$ p3 $h t m$ : fresh ben-oil of the Fortress(32)

L. LIV $b 3 k n d m n$ pr hmt nsw: sweet ben-oil of the estate of the Royal Wife(33) 
L. LV. b3k $n d m n$ st $i n(w)$ : sweet ben-oil of the place of revenues

Hayes identifies the "Fortress" on H. EE as Tjel in the northeast Delta. (34) The problem then remains of identifying the location of the "estate of the Royal Wife" in L. LIV. Considering from the available data, it is highly probable that the estate was located near Memphis or in the Lower Egypt.

A. Leahy also reports two wooden labels with the name of ben-oil (L. 178, L. 179).(35)

L. $178 b 3[k] w 3 \underline{d}$ : fresh ben-oil (Fig. 2-6)

L. 179 b3k w3ㅁ: fresh ben-oil (Fig. 2-7)

No wooden labels have been excavated by the Metropolitan Museum of Art.

7. The Royal Tomb of Amenophis III

The Archaeological Mission of Waseda University did the re-clearance of the royal tomb of Amenophis III (WV-22) in March, 1990.(36) During that time, two wooden labels were found near the entrance outside the tomb. This tomb was studied by Howard Carter in 1915. (37) Carter found nine wooden labels in the room beneath the shaft (the room Ea). According to the notes of Carter, these nine labels and the ones we have found seem to be of similar type. (38) The two wooden labels found by the Waseda University must have been originally excavated by Carter from the same spot in the room E $a$ and dumped outside unnoticed. On the surface of these labels, inscriptions were written in hieratic about ben-oil.

W. WL-1 b3k tpy $n h m \cdot f$ ' $n h$ w $w 3$ snb: ben-oil, the best of His Majesty, 1. p. h. (Fig. 2-4)

W. WL-2 [b3]k tpy $n$.... $\cdot r-h h^{3}$ : ben-oil, the best of .... (T 3$) \cdot r-h 3^{(39)}$ (Fig. 2-5)

The source of ben-oil inscribed on WL-2 as .... -r-hn3 can be identified as $T \cdot r-h 3$ (Salhi) of the northern Syria considering the list of place names of Vol. XXVII 1991 
ancient Egypt. The inscription on this label is the only example where ben-oil is directly related to the actual place name in Syria as the land that produced it.(40)

I have studied the ben-oil in the ancient Egypt concentrating mainly on the problem of its producing land. From the end of the Old Kingdom to the First Intermediate Period, ben-oil must have been brought to Egypt through the contact with Asia, especially with Syrian district. During the Middle Kingdom, ben-oil was a special product of Rtnw (Syria) as shown in the story of Sinuhe. In the New Kingdom, as a result of the expeditions to Asia by Tuthmosis III, a great amount of ben-oil were brought to Egypt. Ben-oil seems to have been produced in the Lower Egypt and at the royal orchard in Memphis as well.

In the royal tomb of Amenophis III, a great number of high quality goods offered at his third sed-festival were placed as funerary goods. Among them was some ben-oil. From the wooden label excavated from the royal tomb, it has become clear that ben-oil from Salhi in the northern Syria was of the best quality. Among the jar labels excavated at the Palace of Malkata, inscriptions indicating that the seeds of moringa tree were brought to Thebes were found. It suggests that probably ben-oil was produced in Thebes after the raw material, that is, Moringa seeds, was transported there. The above fact raises a question regarding the transport and production of ben-oil. After the reign of Amenophis III, a number of jar labels have been discovered at the Palace of Tell al-Amarna though I have not been able to study them in this paper. The exact use of ben-oil as food and medicine is another problem to be studied in the future.

\section{Notes}

(1) Germer, R. "Öle", in Lexikon der Ägyptologie, Bd. IV, S. 552-555, 1982, Wiesbaden, Janssen, J. J. Commodity Prices from the Ramessid Period, Leiden, 1975, pp. $330-337$.

(2) Lucas, A. Ancient Egyptian Materials and Industries, (4th ed.), 1989, London, pp. 331.2.

(3) Germer, R. "Olive", in Lexikon der Ägyptologie, Bd. IV, S. 567, 1982, Wiesbaden Erman, A. und H. Grapow Wörterbüch der ägyptischen Sprache, Berlin, 1982, V, 618

(4) Lucas, A. op. cit. pp. 333-335

(5) The Imperial Institute "Reports of Recent Investigations at the Imperial 
Insitute, Moringa aptera seed from Egypt", Bulletin of the Imprial Institute Vol. XXVIII (1930), pp. 276-279

(6) Manniche, L. An Ancient Egyptian Herbal, London, 1989, pp. 122-123.

(7) Germer, R. Flora des pharaonischen Ägypten, (Sonderschrift 14), Mainz am Rhein, 1985, S. 58.

(8) The Imperial Institute, op cit. p. 276

Germer, R. Katalog der altägyptischen Pflanzenreste der Berliner Mussen, (Ägyptologische Abhandlungen Bd. 47), Wiesbaden, 1988, S. 28, Abb, 28.

(9) The Imperial Institute, op cit. p. 276

(10) Lucas, A. op cit. p. 87

(11) Blackman, A. M. The Rock Tomb of Meir (Part IV), London, 1924

(12) Ranke, H. Die ägyptischen Personennamen, Band I, 1935, S. 90. 8

(13) ibid., S. 90. 11

(14) ibid., S. 195. 30

(15) ibid., S. 90. 9

(16) ibid., S. 90. 12

(17) Newberry, P. et al. Beni Hasan, 4 vols. London, 1893-1900.

(18) Bullock, R. The Story of Sinuhe, London, 1985.

(19) Porter, B. and R. L. B. Moss, Topographical Bibliography of Ancient Egyptian Hieroglyphic Texts, Reliefs and Paintings, I, The Theban Necropolis, Part I, Private Tombs (2nd ed.), Oxford, 1970, pp. 159-163.

(20) Sethe, K. Urkunden der 18. Dynastie, IV, Berlin, 1961, Urk. IV. 59.

(21) Pritchard, J. B. (ed.) Ancient Near Eastern Texts, Relating to the Old Testament. Princeton, 1969, pp. 234-243.

(22) Sethe, K. op. cit., Urk. IV. 688.

(23) Gaballa, G. A. "Three Acephalous Stelae", JEA, Vol. 63 (1977), pp. 122-123.

(24) Porter, B. and R. L. B. Moss, op. cit., pp. 206-214.

(25) Davies, N. de G. The Tomb of Rekh-mi-re' at Thebes, New York, p. 46, pl. XXI.

(26) Sethe, K. op. cit., Urk. IV. 1143.

(27) Davies, N. de G. op. cit. p1. LXIII.

(28) Hayes, W. C. "Inscriptions from the Palace of Amenhotep III," JNES Vol. 10 (1951), pp. 35-40, 82-104, 156-183, 231-242, figs. 1-39.

(29) Leahy, M. A. The Inscriptions, Excavations at Malkata and the Birket Habu 1971-1974, Egyptology Today No. 2 Vol. 4, Warminster, 1978.

(30) Hayes, W. C. op. cit., p. 93, n. 138.

(31) ibid., p. 93-94.

(32) ibid., p. 159.

(33) Leahy, M. A. op. cit., p. 36, p1. 19.

(34) Hayes, W. C. op. cit., p. 93.

(35) Leahy, M. A. op. cit., p. 27, pl. 14.

(36) Kondo, J. "A Preliminary Report on the Re-clearance of the Royal Tomb of Amenophis III (WV 22)", in After Tutankhamun (ed. by C. N. Reeves), London, 1991 (in press).

(37) Carter, H. (GI), I. J. 386, no. 97.

(38) Kondo, J. "Hieratic Inscriptions from the Tomb of Amenophis III", Orient Vol. XXVI (1990), pp. 94-104.

(39) ibid., p. $97,104$.

(40) ibid., pp. 97-98. 

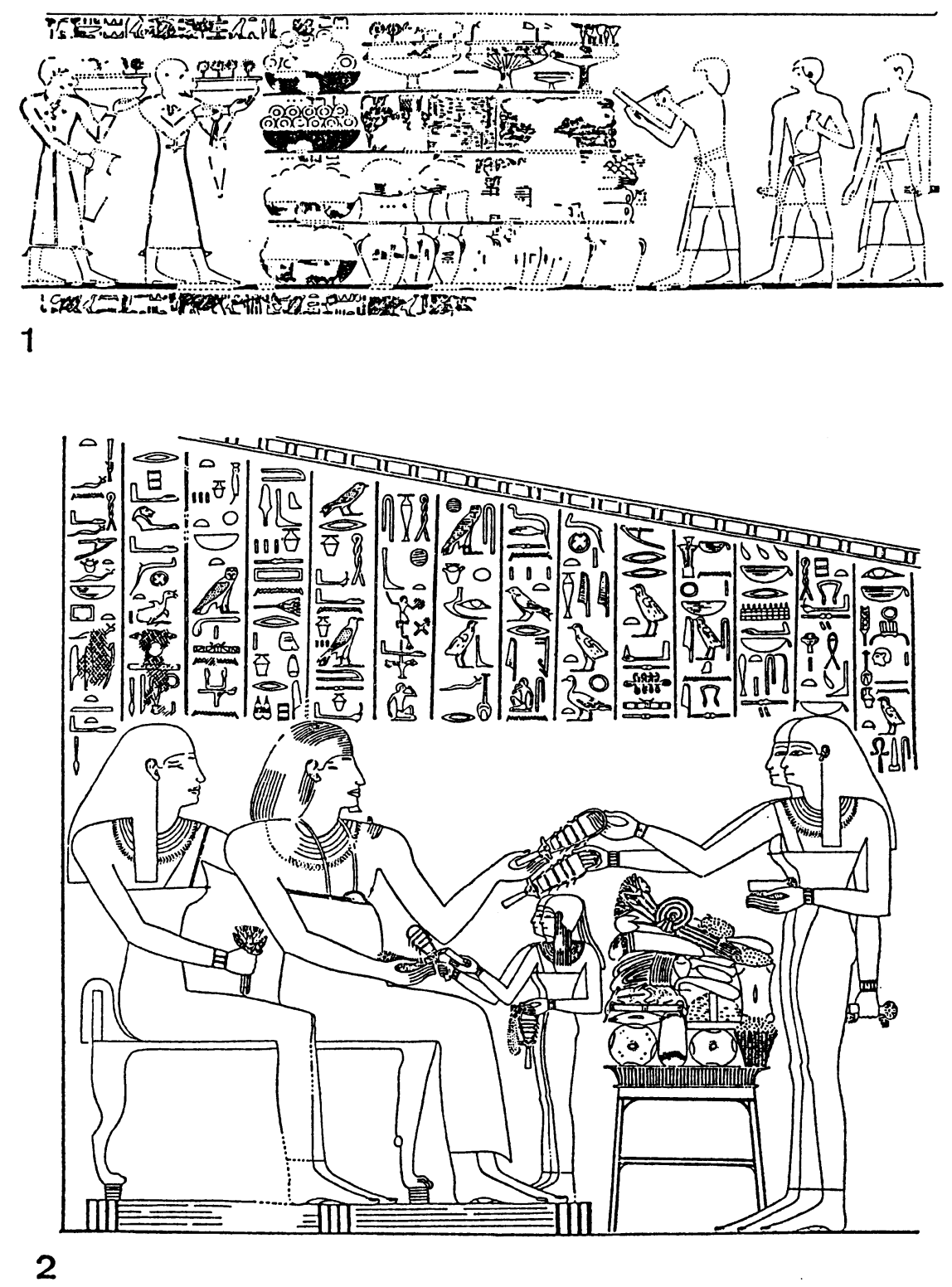

Fig. 1. Wall scenes from the tomb of Rekhmira (T.T. 100)

(1. Gifts from Syria. 2. Rekhmira and his wife Meryt sat to receive sistrums and menits from their daughters. : after N. de G. Davies, 1944) 
BEN-OIL IN ANCIENT EGYPT
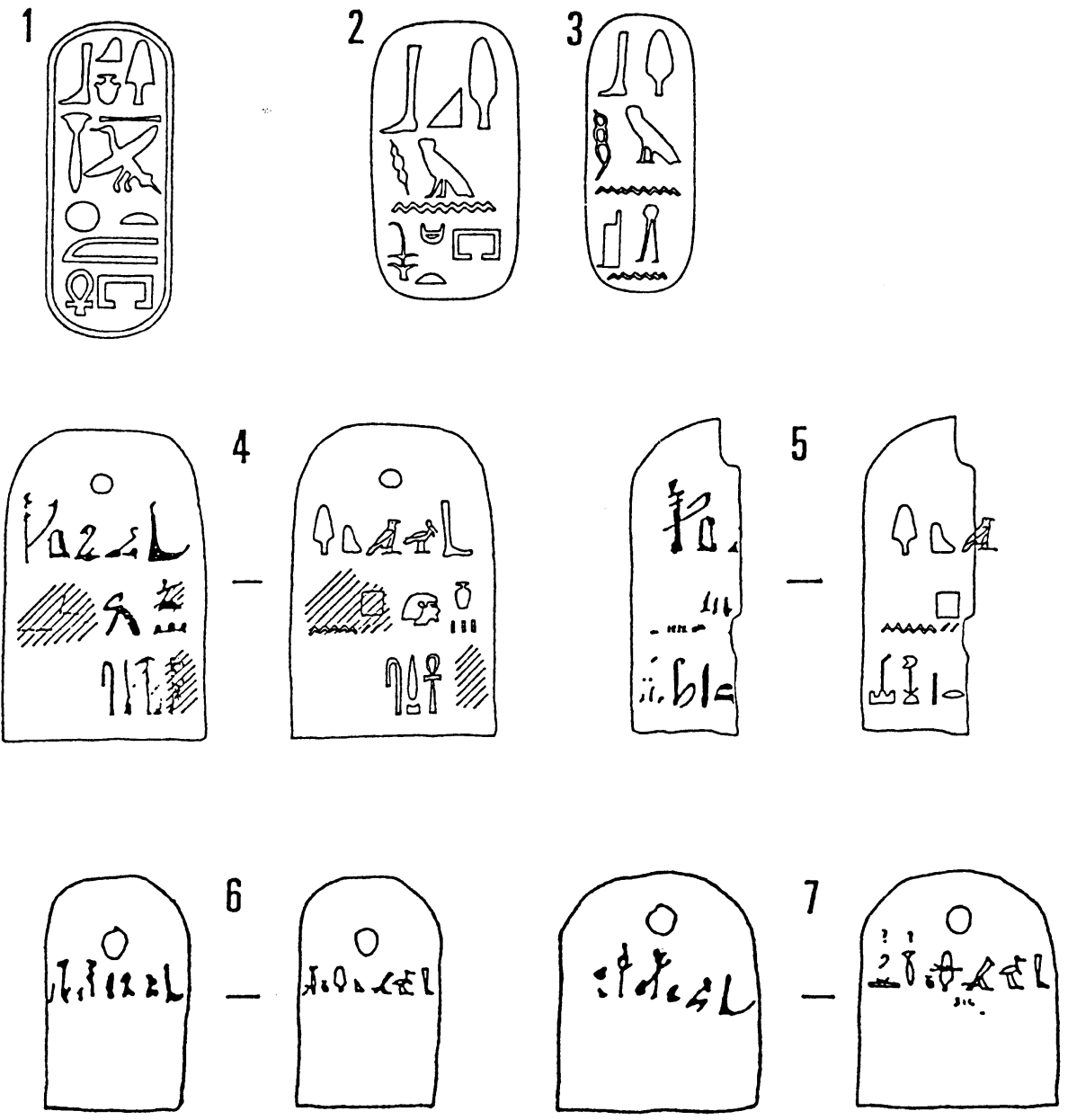

Fig. 2. Jar sealins and wooden labels (1. H.EE 2. L.LIV 3. LV 4. W·WL-1 5. W.WL-2 6. L. 178 7. L.179) After W.C. Hayes(1), M. A. Leahy $(2,3,6,7)$, J. Kondo $(4,5)$ 